University of Nebraska - Lincoln

DigitalCommons@University of Nebraska - Lincoln

2009

Who Gets to Be the Expert?: Legal Research Skills Certification in Legal Education

Richard Leiter

Follow this and additional works at: https://digitalcommons.unl.edu/lawlibrary

Part of the Law Librarianship Commons, Legal Profession Commons, and the Legal Studies Commons

This Article is brought to you for free and open access by the Law, College of at DigitalCommons@University of Nebraska - Lincoln. It has been accepted for inclusion in The Marvin and Virginia Schmid Law Library by an authorized administrator of DigitalCommons@University of Nebraska - Lincoln. 


\title{
Who Gets to Be the Expert?: Legal Research Skills Certification in Legal Education
}

\author{
Richard Leiter \\ Schmid Law Library, University of Nebraska College of Law, Lincoln, Nebraska, USA \\ Correspondence - Richard Leiter, Schmid Law Library, University of Nebraska College of \\ Law, 1301 North 37th Street, Lincoln, NE 68503; email: rleiter@unl.edu
}

\begin{abstract}
This article considers the question of whether there is a need for law schools to offer certification for specialization in legal research skills and discusses various approaches to legal research skills certification. The author argues that it is unnecessary to offer legal research certification as it is presupposed that a basic legal education should include instruction in how to find and read the law. Anything less is a failed legal education.
\end{abstract}

Keywords: legal education, legal research instruction, certification in legal education

Exactly how special are legal research skills? Are they special enough to warrant certification? As a matter of fact, the act of legal researching is so intimately connected with the practice of law as to be indistinguishable. After all, is it even possible for a lawyer to practice law without reading it? And is it possible to read the law without finding

Published in Legal Reference Services Quarterly 28 (2009), pp 271-280.

DOI: $10.1080 / 0270319090296161$

Copyright (C) 2009 Taylor \& Francis Group, LLC. Used by permission. 
it? And finding the law is not only the name of one of the great textbooks on legal research, ${ }^{1}$ it's also the very act of research itself. For many years, legal research has been treated as a discipline separate from so-called doctrinal courses in law schools. But this was not always the case. In the early history of legal education, it was impossible to divide the study of law from legal researching. This essay will examine whether there's a need for legal research subject certification in the context of the development of legal research instruction in legal education.

In order to get to an understanding of how we might answer this question, we must first examine what is legal research: Is it knowledge or is it a skill? The corollary is, perhaps, even more problematic: How do we recognize someone with proficiency that warrants certification? Can a skill like this be objectively measured? In my opinion, it is questionable that it can be effectively measured. The thing that can be measured, however, is whether a student has taken the appropriate courses and passed them. In the end, this may be all that we can hope for-that students take all available research and subject specialty courses and pass them.

\section{What is legal research?}

The short answer to this question is that legal researching is the ability to find information that answers legal questions. Legal research ability is difficult to judge in part, because in the modern world of legal bibliography, there are often many alternate ways to find needed legal information. As long as the researcher finds the information that $\mathrm{s} /$ he needs to form opinions, advise clients, or make legal arguments, who is to say that her method is right or wrong?

In the book, Educating Lawyers, ${ }^{2}$ a very fine and very detailed examination of the state of American legal education, the discipline of legal research receives no more than a page or two of mention. ${ }^{3}$ Even then, it is mentioned only indirectly. It is easy to look at this omission and conclude that legal research was given short shrift or ignored to the detriment of our entire vocation. Librarians, the legal research experts, have often been inclined to feel like the Rodney Dangerfield's of the legal profession: We don't get no respect! 
A more careful look at Educating Lawyers reveals some important facts about the development of legal education that show how legal research came to be a rather late addition to the law school curriculum. Legal education only became a regular part of the modern university in the late nineteenth century when Langdell is credited with developing what is now considered the standard form of legal education, the so-called "case method." Prior to this, legal education was basically a process of apprenticeship, called "reading the law." This method of studying the law involved working for an established attorney and reading the law under his direction.

As absurd as it sounds, "reading the law" was entirely feasible well into the nineteenth century. James Kent, in his Commentaries on American Law, notes that reading the law had, by that time, become very difficult due to the proliferation of serial law reports. ${ }^{4} \mathrm{~A}$ careful look at his footnotes reveals that the total collection of law books extant in his day was only a little more than 800 books. A student in his day would have been required only to read a fraction of these books in preparation for admission to the bar, since s/he would have only had to be familiar with the cases and statutes of their state. By contrast, it was not until the dawn of the industrial revolution and the astounding commercial success of the great legal publishing houses that the bibliography of the law proliferated to an extent that made mastery over the content of primary and secondary legal materials nearly impractical.

It seems obvious that a lawyer preparing for practice in the nineteenth century would have become intimately acquainted with the majority of sources of the law as s/he studied the law. Even under Langdell's method, as students were reading cases, there were not many options to which to turn to find the cases they were reading. In the early days of legal education, then, is it any wonder that legal research as a skill was not given much attention?

\section{The legal research skill}

Agents of legal publishers first taught legal research in law schools near the turn of the twentieth century. ${ }^{5}$ It is hard to imagine that this was not largely a marketing tool. In those days, as is true in the present day, it was probably the case that these publishers' representatives/ 
instructors tended to favor their own publications over the competition. The good news was, of course, that since the publishers were publishing mostly primary legal materials, it was unlikely that the relative characteristics of the competing materials had much to do with accuracy, and likely that they had more to do with layout, design, and usability.

And so, in the early history of legal education, legal research instruction was largely taken for granted because students studying the law were getting intimate experience with its sources precisely because they were studying the law. The idea that lawyers needed instruction about legal research may have, indeed, seemed as absurd as a school for carpenters teaching students how to use a hammer. ${ }^{6}$

As legal publishing grew to become an industry and commercial publication of legal materials proliferated, legal research as a distinct discipline came into its own. During the Industrial Revolution and the New Deal era, the numbers of primary legal materials increased exponentially. The United States Code and the Code of Federal Regulations only came into existence in the third decade of the twentieth century! With this explosion of statutory and regulatory materials, together with a corresponding boom in case law, came an enormous growth in importance and numbers of secondary materials to explain it all. The need for expertise in collecting, managing, and using legal materials became increasingly necessary during this period. Arguably, before this, studying the law was, essentially, studying the laws themselves, therefore making the study of legal research all but redundant. Prior to this explosion of legal bibliography, expertise in a specific legal subject implied expertise in the bibliography of that area of practice. After all, how could one study bankruptcy and not study the sources of bankruptcy law?

The state of legal bibliography today is quite complex. Not only are there more statutes and regulations (not to mention more cases) with which lawyers must be familiar, but virtually all federal and state agencies have developed numerous official and quasi-official legal documents, such as Private Letter Rulings, policy statements, press releases, as well as operating and procedure manuals that are every bit as important to practice as the statutes, regulations, and cases themselves. 7 Today, expertise in the bibliography of law in a specific subject can no longer be presumed. 
Electronic publication and access to legal materials has had an exponential effect on the complexity of legal researching. Where once there were only two or three sources of access to certain statutes or regulations, there may now be a dozen. Even with respect to multiple publications of primary materials, quality and authenticity of the sources cannot be presumed. The proliferation of sources complicates not only the use of materials, but factors, such as physical space, cost, and user licenses, make the process of collecting and managing them as important as using them.

Further complicating the geography of legal bibliography is the advent and importance of blogs, podcasts, and Web sites as vehicles for policy statements and other crucial legal pronouncements and guidance from pundits, scholars, and government officials. Arguably, a lawyer's legal skills today must include much more than simply knowing how to use the materials; a lawyer must also be thoroughly grounded in the bibliographic history of the materials she uses and be able to evaluate their relative merit, usefulness, and value. Of course, lawyers fortunate enough to have a librarian on staff may be able to rely on their special expertise for much of this evaluative and management function.

\section{Certification of legal research skills}

Turning to the question of whether law students could be, or should be, certified as "legal researchers," it is clear that the skills that would be subject to certification are very complex and, in some ways, very subtle indeed. With myriad sources of legal information available to researchers, would legal research certification measure outcomes or processes? This complexity is reflected in the various approaches to teaching legal research.

There are four general models of legal research instruction, each with its own merit and each receiving considerable attention in the literature. They will only be briefly detailed here. They can be broadly defined as the "bibliographic method," most recently championed by Bob Bening and Kathleen Vanden Heuvel; 8 the "process method" described in detail by Jill and Christopher Wren; 9 the topical method, described by Peter Schanck; ${ }^{10}$ and, finally, the "practice or pragmatic method," such as that used at William and Mary School of Law. ${ }^{11}$ 
The bibliographic method trains lawyers to understand how the bibliography of the law is structured and how it works. The virtue of this method is that students learn the sources of the law independent of their format or publication method and are, therefore, equipped to discover and explore new platforms for delivery of the materials they need in their work. They are also well equipped to evaluate different platforms and assess their relative value depending on the immediate task at hand. By subtle contrast, the Wrens' approach focuses on the way the various platforms and publications work, how they are structured, and their relative pragmatic characteristics. An important aspect of this approach is that it also emphasizes systematic methods for conducting research based on the desired outcome or the specific circumstance for which the research is being conducted. The benefit of this approach is that it equips lawyers with the practical skills for using each kind of research tool covered in the class.

The topical method emphasizes special training in subject specialties. This method is used in many ways. In some schools, short classes are offered on various topics throughout the school year; for example, a course may be offered in securities or tax law. In others, research instruction may be incorporated into the courses themselves. For example, a class in municipal law may bring in a librarian to offer instruction on the use of materials and methods researching municipal law. In these situations, research instruction may be offered in a single class session or it may be introduced at various times throughout the course so that the bibliographic instruction is offered at appropriate times as the material is covered in the course.

The "practice" method teaches law students how to research in the context of writing exercises and forces the student to learn research skills as they are needed to solve real, albeit fictitious, legal problems as they are drafting various legal documents. There is much to value in this approach because it recognizes legal research as a skill that is most easily learned when used and practiced.

As a practical matter, each method can produce fine, intelligent researchers. But in practice, the bulk of research skills are learned by young lawyers and law clerks on the job as they learn to use the resources available to them in their law offices and as they learn the ins and outs of their practice specialties. Given the way that sources of the law are multiplying, and the growing complexities for gaining 
access to the materials-and particularly given the introduction in the last few decades of so many online resources and their licensing agreements, consortium arrangements, and bulk updating contracts for traditional materials (whew)-it is understandable that few, if any, lawyers can hit the research ground running in law practice or clerking positions. Senior lawyers at law firms understandably perceive a decline in the researching skills of new graduates. After all, when they were young, there may have been only a fraction of the resources available. We should not forget that a little more than thirty ${ }^{12}$ years ago, Lexis came into being and during that same time span the lawbook publishing landscape would so change that now the two biggest and legal publishers of American primary and secondary law are no longer U.S. corporations. ${ }^{13}$

In this context, the question of whether certification of law graduates' legal research skills is valuable becomes very difficult to answer. What skill can be certified? Should graduates be able to recite lists of sources for the Treasury Department's General Counsel Memos or be able to list the "best" source? And who could possibly determine the "best" source for many primary materials? Try as they might, in the face of an ever-changing legal bibliography, it is doubtful that either The Bluebook or Association of Le gal Writing Directors citation formats will be able to exert much authority as standards for best resources. Rather, they will simply remain what they really always have been-style books, and not much more.

Law students arguably should be trained in a litany of steps to take when researching certain legal questions. For example, should students be able to list the steps to be taken or resources consulted when researching the protections available to a software engineer who has developed a utility written to mine information from various commercial Web sites? In any scenario, while the learning curve of a new lawyer may be steep, s/he will soon become proficient in the day-today access to the materials needed in their practice. Such proficiency will be molded by the materials and resources at her disposal and by the nature of her practice, be it litigation, advisement, or drafting. For example, if the firm owns the Bureau of National Affairs' (ENA) Labor Relations Reporter, but not the Commercial Clearing House, Inc. Labor Law Reports, it will be understandable that the lawyer will know the ENA materials best. If the firm has an exclusive arrangement with 
Westlaw, it is natural to assume that the lawyers in the firm will have little skill or familiarity with Lexis.

In the end, legal researching is clearly more than merely knowing how to use the different services. Collecting and managing the materials best suited for practice may be just as important, and if we assume that certification of legal research skills means the certificate warrants a high degree of familiarity and expertise with legal research and bibliography, then there also needs to be some way of measuring familiarity with these skills or this knowledge as well. Quantifying such proficiency or evaluating such knowledge may, in fact, be nearly impossible given the fluidity and growth in legal materials.

It can also be argued that any lawyer studying law should know from where the law comes. That is, if one has taken a course in environmental law, the student should be exposed to the documents that govern the issues of environmental law. In a perfect world, such a student should not need separate instruction on how to research environmental law. It would be redundant and so would certification: if a student were to earn a certificate in environmental law or family law, for instance, it should be presumed that s/he is something of an expert in the bibliography of that field. Perhaps one important contribution that librarians can make to legal education would be to ensure that such certification programs include a research aspect to them.

There is a very subtle conundrum to be considered when discussing the merit of legal research certification. It seems logical that students who receive subject certification in a field such as trial practice, business law, or taxation should have some degree of expertise about research in that field. ${ }^{14}$ The presumption is that all law students are experts in basic legal knowledge, which is usually covered in the first three semesters of law school. Certification of a specialized field of legal knowledge, such as business transactions, denotes study of a group of classes beyond those of a typical law graduate. Thus, it seems absurd to offer certification in a first-year subject such as contracts or torts, because all students are presumed to be familiar with these subjects. (Obviously, there is room for in-depth study of these subjects, and students may pursue graduate degrees in such subjects, or may choose to teach them and in the process become experts in contracts or torts.) 
If a school were to offer certification in legal research, what skills would be certified? If certification is being proposed for general legal research skills, as contrasted to expertise in a particular subject specialty, then we are talking about broad expertise in legal bibliography. As discussed above, expertise in legal research transcends mere knowledge or skill in how to find materials. Today, true expertise in legal research demands much more than that. Knowing where to look for specific answers will not do much good without access to them. Experts in legal research must be able to evaluate resources and make judgments about collecting, organizing, and managing them, as well as simply knowing open Web sites or using indexes and books to find answers. The fact is, virtually all reference librarians, particularly in the academy, have advanced degrees in librarianship or information sciences. Law reference librarians who have law degrees and library degrees are certified (in an informal way) as experts in legal research and bibliography.

All things considered, legal research certification may have practical value for law students in the job market. There is a general perception that new lawyers are graduating with inadequate practice skills (read: research, among others) and law students looking to distinguish themselves from their peers in the job market may find that certification is an important way to do so. Successfully completing an advanced legal research (ALR) class should qualify as evidence of proficiency in legal researching whether taking the class earns the student a certificate or not. Taking specialized law courses or a series of courses, too, should signal to prospective employers that the student has more than a basic understanding of how to perform research in those areas of practice. While one may argue (and some do) that taking a course on, for example, government contracts does not necessarily produce students who are good government contracts researchers, it is obvious that this is a failure of the particular course's pedagogy and should not be an expected outcome of a specialized course; taking a class to become an expert (or at least taking the first step toward becoming one) should surely include attention to the documents and bibliography of the subject, shouldn't it?

Online legal database vendors have occasionally toyed with the idea of offering students the opportunity to earn certificates of proficiency in use of their systems. Both Lexis and Westlaw have offered such 
training over the years, because, they say, employers are anxious to hire people who can maximize the use of their systems for the least cost, therefore making students with these certificates attractive hires. But there is more than a little subtext to these schemes. For one thing, both companies will, of course, emphasize their own services' value vis a vis the competition, turning the certification program into a blatant marketing tool. And students who earn a certificate in only one system may inadvertently limit their marketability to those firms with exclusive contracts to that service. But no matter how you look at it, certification by a publisher in the use of its own products will probably always be looked upon with suspicion because it is, by definition, if not necessity, self-serving.

There are also pedagogical reasons for doubting the value of publisher certification of expertise in the use of their own materials. Legal bibliography and legal researching in any specialized practice is not something that comes from a single source. Even though there are some fields that are dominated by one or more treatise or loose-leaf, no practitioner can be a successful researcher if proficient in only one resource. While the great standard works of the law are, indeed, valuable and complex and worthy of special attention in order to master, it is difficult to imagine that a law student would benefit from certification as an expert in the use of Collier's Bankruptcy Reporter, Wright and Miller, or the Restatements.

\section{A word about certification in other disciplines}

Some have argued that since other disciplines, such as auto mechanics, electricians, or medical doctors, have certification procedures, so should general law. But there are distinct differences between certification of lawyers in specialties and certification in other professions or crafts. A detailed discussion of the processes of certification in other professions is beyond the scope of this article, and so what follows is a general discussion of how certification of legal specialties, especially certification of legal research skills, may differ from those mentioned above.

Certification in many of these other disciplines is often linked with licensure, or with measuring objective expertise (in the sense that certification means that the person certified has completed certain 
classes, workshops, or training) that may affect public health or safety and transcends mere marketing value. However, an auto mechanic who is certified by a particular automobile manufacturer may be no better at fixing that brand of car than one who is not, but from the consumers' point of view, certification is a fact that implies expertise and helps build trust and confidence. In this context, it is interesting to ponder whether clients are more apt to hire a lawyer with a certification in Westlaw or Lexis. I think not.

In other professions, such as electricians, licensure may be a legal matter, and someone who attempts to practice as an electrician may violate not only state and local laws, but s/he may also run afoul of union contracts. Since safety is at stake, most consumers will prefer a licensed electrician to one who's not, regardless of the legal consequences.

In the case of the medical profession, board certification of medical specialties is interwoven with marketing, safety, and expertise about procedures or treatments affecting life or death. But in these cases, certification is much more than merely taking a class and passing a test: many medical board certifications require years of residency and training. By comparison, most academic legal certifications are more about a student marketing her special skills to potential employers than certifying her skills to potential clients. What's more, a student who graduates without a certificate in government contracts, for example, is free to take on clients with government contracts legal matters and practice in that area as well as write wills or handle criminal matters. Many lawyers have specialized practices, which usually are the result of successfully handling certain types of cases and establishing a reputation for that expertise. Expertise or specialization in law is usually the result of good law school training combined with experience. For reasons set out above, legal research as a certified legal practice skill does not fit easily into any of the other models for professional certification. ${ }^{15}$

\section{In conclusion}

Instead of lobbying for legal research certification, law librarians should perhaps strive in earnest to make effective legal research skills training an integral part of the law school curriculum. As a device to 
help law students compete in the job marketplace, certification may be very valuable, and law schools and librarians may want to consider ways to facilitate this purpose by offering a rich variety of exposure to legal bibliography over the course of a law school career: research courses, basic, advanced, and specialized, as stand-alone courses or integrated into doctrinal courses. Whether certificates are granted or offered, their completion and recordation on transcripts or inclusion in students' resumes should serve to let employers know that the student has a certain level of proficiency in legal researching.

As a practical matter, however, the best way to prepare students for practice is by offering quality education, and that must include offering as much attention as is practical to the study of the sources of the law. Legal bibliography should be offered at all phases of legal education and at appropriate times: basic materials in the first year, detailed studying of the bibliography of law in elective ALR courses and focused attention to the sources of the law in all upper division electives, particularly in disciplines governed by specialized sets of legal materials. With care, a law degree can be its own certification of proficiency in legal research skills.

\section{Notes}

1. Morris L. Cohen, Robert Berring \& Kent C. Olson, How to Find the Law (9th ed., West Publishing 1989).

2. William M. Sullivan, et al., Educating Lawyers (Jossey-Bass 2007)

3. Richard Leiter, The Missing Lawyering Skill, 12 AALL Spectrum 22 (O. Halsted 2007-2008).

4. James Kent, Of Reports of Judicial Decisions, in Commentaries on American Law (“Kent's Commentaries") vol. 1, 439 (1826).

5. Woxland, ed., Introduction, Symposium of Law Publishers, 11:3/4 Leg. Ref. Servs. Q. 1 (1991)special issue; see also, Woxland, Why Can't Johnny Research? or It All Started with Christopher Columbus Langdell, 81 L. Lib. J. 451 (1989).

6. To satisfy the cynical who may take issue with the analogy, it should be noted that, indeed, there are different types of hammers for different types of jobs and different hammer manufacturers. But presumably a hammer used for roofing would be covered in roofing classes, and finishing hammers would be covered in courses about finishing carpentry. The notion of a whole class on hammer using-"Hold the nail, raise the hammer and pound!"-is the scenario that seems absurd ... 
7. By way of example of the increase in volume of primary legal material, consider the following: Volume one of the Code of Federal Regulations occupied about six linear feet of shelf space in 1970; today it occupies more than twenty feet. The Federal Register, too, has grown to staggering proportions. In 1936, volume one contained a total of 2,411 pages; ten years later, in 1946, it contained 14,736 pages. By 2006, it had grown to its present average size of well over seventy thousand pages, after topping out at 83,294 pages in 2000. Case law, too, has increased in size. In its first year of publication, the Federal Reporter needed volumes one through five to contain all the cases from 1880. By 1980, it took twenty-seven volumes to contain the cases from that year, and by 2000 , thirty-eight volumes were needed.

8. Robert Berring and Kathleen Vanden Heuval, Legal Research: Should Students Learn It or Wing It? 81 L. Lib. J. 431 (1989).

9. Christopher G. Wren \& Jill R. Wren, The Teaching of Legal Research, 80 L. Lib. J. 7 (1988)

10. Peter Schanck, Mandatory Advanced Legal Research: A Viable Program for Law Schools? 92 L. Lib. J. 295 (2000).

11. The program at William \& Mary is an integral part of the legal skills curriculum described in detail in Moliterno, The Legal Skills Program at the College of William and Mary: An Early Report, 40 J. Leg. Educ. 535 (1990). The research component was well presented and described by James A. Heller, Teaching the Teachers: Effective Instruction in Legal Research, (Austin, Tex., Oct. 18-20, 2007) (see http://tarlton.law.utexas.edu/ttt for a complete description of the program).

12. Some colleagues have pointed out that Lexis was invented in the 196os, and that therefore, this number should be forty years ago. All I can say is that Lexis didn't become widely available until the late 1970s. So, while it may have been invented in the 1960 s, it didn't find its way into law firms or law schools until later; so, I will stand on my "thirty years" assertion. Maybe I'm stubborn, or maybe I'm just not ready to concede that anything important that occurred during my adult years could have happened forty years ago.

13. West is owned by Thomson-Reuters, a Canadian/Dutch company, and Lexis is owned by Reed Elsevier, a Dutch/British publishing house.

14. I am assuming that a student who takes a specialized course of study in tax law learns more than the simple fact that unique materials, such as Private Letter Rulings exist, but also learn how they are made, where they come from, and how to find them. It is incomprehensible to me that anything else can be the case. I hope that I'm not being naive.

15. That is, because there is no "right" way to find legal materials due to the myriad ways they are published and/or distributed. In fact, even for primary materials, there may be as many as a dozen reliable sources for legal materials. In this situation, who could certify that one way for finding the material is correct and another is not? 